\title{
Waarom zorgen mannen niet meer?
}

\author{
Justine van de Beek
}

Aan het begin van de coronacrisis klonken er hoopvolle geluiden. Velen zaten nu gedwongen thuis, en dus ook mannen die zich normaliter grotendeels aan het gezinsleven onttrekken. Dit was dus goed nieuws voor de betrokkenheid van vaders. En dat de betrokkenheid van vaders weer goed nieuws is voor de relatie tussen hetero partners (Carlson, Hanson \& Fitzroy, 2016) en voor de ontwikkeling van hun kinderen (Altintas \& Sullivan, 2017; Keizer e.a., 2020) is bewezen.

De NRC-kop (Hoving, 2020) over onderzoek in mei vorig jaar sprak echter boekdelen: 'Vaders doen sinds coronacrisis meer in huis, zeggen ze'. Er vond naar eigen zeggen inderdaad wat meer vaderlijke betrokkenheid plaats, zag socioloog Mara Yerkes van de Universiteit Utrecht, maar nog steeds meldden vrouwen dat zij het leeuwendeel aan kindzorg en huishoudelijk werk op zich namen. In hetzelfde artikel reflecteert de hoogleraar Renske Keizer van de Erasmus Universiteit op haar eigen onderzoek naar dit onderwerp: zij zag dat alleen hoogopgeleide vaders meer zijn gaan zorgen, en dat hun vrouwelijke partners die stijging níet bevestigen.

$\mathrm{Al}$ met al heeft deze pandemie dus niet geleid tot een transformatie van zorgtaken in het Nederlandse gezinsleven. Meer aanwezigheid staat niet gelijk aan meer betrokkenheid. Dat is niet verbazingwekkend, omdat een ongelijke verdeling van zorgtaken diep ingesleten zit in het beleid en de cultuur in Nederland. In 2010 wees onderzoek uit dat Nederlandse vaders 27 minuten besteden aan kindzorg voor elk uur dat Nederlandse vrouwen dat doen (The Fatherhood Institute, 2010). Alle OECD-landen, behalve Oostenrijk, scoorden hoger dan Nederland in dat onderzoek.

Decennialang kregen partners in Nederland maar twee dagen kraamverlof: 48 uur om kennis te maken met je nieuwe kind en om je net bevallen partner te ondersteunen, en weer door. Vele vaders namen daardoor gedwongen andere soorten verlof op. Pas sinds 2019 is het kraamverlof voor partners vijf dagen bij een fulltime dienstverband. En pas vanaf juli 2020 hebben zij recht op vijf weken aanvullend verlof, doorbetaald op 70 procent van hun salaris. In 2022 moeten er nog negen weken op 50 procent doorbetaald volgen, kondigde het kabinet aan. Het zijn stappen in de goede richting, maar zet geen zoden aan de dijk als je het vergelijkt met de zestien weken volledig doorbetaald verlof voor moeders. Voornamelijk vaders die weinig verdienen of niet in loondienst zijn, delven hier het onderspit. Zij kunnen het zich moeilijk veroorloven langere tijd verlof op te nemen tegen een aanzienlijk lager salaris.

Waar een wil is, is een weg, zou je kunnen denken. Maar aan die wil ontbreekt het hem ook vaak. Goed vaderschap betekent veelal nog steeds de kost winnen (Yarwood, 2011; Eerola \& Mykkänen, 2013). In de traditionele, klassieke definitie van

* Justine van de Beek MSc werkt als campaigner bij stichting DeGoedeZaak. 
mannelijkheid staan betaald werk en een distantiëring van vrouwelijkheid en daarmee zorgzaamheid centraal. In mijn masterscriptie (Van de Beek, 2020) over mannelijkheidsidealen onder in deeltijd werkende Nederlandse vaders omschreef een respondent het treffend: hij had het niet zo met zijn macho buurman die het vertikt om luiers te verschonen, maar vond zichzelf als meer verzorgende vader ook zeker geen 'mietje'. Zelfs vaders die bewust kiezen om deeltijd te gaan werken vanwege kindzorg, reproduceren een bepaald mannelijkheidsideaal waarin 'vrouwelijkheid' en zorgzaamheid ver te zoeken zijn. Nederlandse vaders doen over het algemeen wat meer dan vroeger, maar vervullen meestal alsnog een bijrol als trainee, waarbij de moeder de manager in het gezin is. In Scandinavische landen zoals Zweden heeft de overheid het dan ook op zich genomen om in landelijke en regionale campagnes gelijke zorgverdeling te stimuleren (Almqvist \& Duvander, 2014).

Beleid kan die traditionele normen en waarden niet volledig transformeren, maar er zijn wel ingenieuze beleidsprikkels die ingebouwd kunnen worden. Dat begint natuurlijk bij een egalitair fundament waarbij zowel moeders als partners evenveel recht hebben op verlof, met volledige vergoeding. De ingewikkelde kinderopvangtoeslag die zoveel Nederlandse ouders de afgelopen jaren de afgrond in heeft gewerkt, kan worden afgeschaft als geld direct naar kinderopvangen gaat en kinderopvang gratis voor de gebruikers wordt. En om vaders te prikkelen om hun verlof echt op te nemen kan er een zogeheten 'daddy quota' ingevoerd worden, zoals in Noorwegen, Zweden en IJsland. Er is dan een gedeelte van het verlof specifiek gereserveerd voor vaders. Wanneer ze het verlof niet opnemen, vervalt het en kan de moeder het dus ook niet meer opnemen. De 'daddy quota' is in die landen succesvol gebleken: veel meer vaders namen kindzorg op zich na de introductie van deze maatregel. Het kan dus anders.

Maar waar deze zorgongelijkeid vooral om vraagt is een herwaardering van zorgwerk, waaronder kindzorg. Een Nederlands televisieprogramma over dit onderwerp heette notabene 'Waarom werken vrouwen niet?'. Het hele probleem is nu juist: vrouwen werken wel, maar we zien onder andere kindzorg niet als 'echt' werk. Zolang het narratief altijd gericht is op vrouwen die te lui of gepriviligieerd zouden zijn om betaald werk te doen, blijven we in de mal waarin we vrouwen forceren zich te voegen naar de heersende norm onder mannen (voltijd betaald werk). De alternatieve en meer boeiende vraag is de volgende: waarom zorgen mannen niet meer? Waarom is het zo, binnen de mannelijke identiteit en binnen beleid, dat de ruimte om een hechte band met je kinderen op te bouwen ondergeschikt is aan een carrière? Het wordt ook wel reproductieve arbeid genoemd - het werk van veelal vrouwen dat gezinnen laat voortbestaan en onzichtbaar de economie draaiende houdt. Yvonne La Grouw schrijft in deze editie over zorgzaamheid als essentieel organiserend principe en uitweg uit de coronacrisis als feministisch drama. Dat is de crux: zorgzaamheid is al het fundament van deze samenleving. $\mathrm{Nu}$ nog de erkenning, en de uitbreiding naar die groep die nooit blijkt te hoeven emanciperen: mannen. 


\section{Literatuur}

Almqvist, A.L., \& Duvander, A.Z. (2014). Changes in gender equality? Swedish fathers' parental leave, division of child care and housework. Journal of family studies, 20 (1): 19-27.

Altintas, E., \& Sullivan, O. (2017). Trends in fathers' contribution to housework and childcare under different welfare policy regimes. Social Politics: International Studies in Gender, State \& Society, 24 (1): 81-108.

Beek, J. van de (2020). Beyond the absent breadwinner: mapping the paternal masculinities of Dutch highly involved fathers. Erasmus University Rotterdam.

Carlson, D.L., Hanson, S., \& Fitzroy, A. (2016). The division of child care, sexual intimacy, and relationship quality in couples. Gender \& Society, 30 (3): 442-466.

Eerola, P., \& Mykkänen, J. (2013). Paternal Masculinities in Early Fatherhood. Journal of Family Issues, 36 (12): 1674-1701.

Hoving, D. (2020, 25 mei). Vaders doen sinds coronacrisis meer in huis, zeggen ze. NRC. www.nrc.nl/nieuws/2020/05/25/vaders-doen-sinds-coronacrisis-meerin-huis-zeggenze-a4000711.

Keizer, R., Lissa, C.J. van, Tiemeier, H., \& Lucassen, N. (2020). The Influence of Fathers and Mothers Equally Sharing Childcare Responsibilities on Children's Cognitive Development from Early Childhood to School Age: An Overlooked Mechanism in the Intergenerational Transmission of (Dis) Advantages? European Sociological Review, 36 (1): 1-15.

The Fatherhood Institute (2010). The fatherhood report 2010-11: the fairness in families index.

Yarwood, G.A. (2011). The pick and mix of fathering identities. Fathering, 9: 150-168. 